and a survey of soil resources is being actively pursued. To standardize techniques and nomenclature and to assist the surveyor, a compact guide to the description and mapping of soils has been produced: Soil Survey Manual for Malayan Conditions, by M. L. Leamy and W. P. Panton (Pp. $\mathrm{x}+226$. Ministry of Agriculture and Cooperatives, Malaysia. Division of Agriculture, Bull. No. 119. Kuala Lumpur, 1966. 11s. 8d.). There are brief descriptions of the geography, parent material, vegetation and physical features of the country, followed by instructions on examining and describing the soil profile. There follow descriptions of mapping units and classification with emphasis on the special difficulties in Malaya presented by inaccessible forest regions, swamps and steep hills. Aerial photographs have been of limited use, but a geological map ( 1 in. to 12 miles), a rainfall map, and good quality topographic maps are available. The mapping scale of 2 in. $-2 \frac{1}{2}$ in. to 1 mile has been chosen for reconnaissance survey purposes. About 100 soil series have been accepted as a basis of a register, but classification will remain fluid until more data have been collected. Many of the main series are in the great soil groups: reddish-brown latosols and yellow latosols, ground water laterite, yellow podsolic, organic and alluvial.

\section{Protection for Tuna}

ATLANTIC tunas will share with whales some immunity from hunting as a result of a convention on conservation drafted, by the representatives of seventeen nations, at what is called the Conference of Plenipotentiaries on the Conservation of Atlantic Tunas held at Rio de Janeiro in May this year. The convention has been prompted by evidence in recent years that more boats are chasing fewer fish. It applies to the whole of the Atlantic Ocean and adjacent seas, and the hope is that it will maintain the population of tuna and tuna-like fish, defined as the Scombriformes with the exception of the families Trichiuridae and Gempylidae and the genus Scomber, at those levels which permit the greatest sustainable catch. The commission that will be responsible for administering the convention when this has been ratified by at least seven countries will be empowered to collect information and to recommend research programmes. It may also, on the basis of the evidence it collects, recommend limits on the rate of catch in the convention area.

\section{Parliament in Britain}

Answering questions in the House of Commons on June 16, the Prime Minister, Mr. H. Wilson, announced the Government's decision that responsibility for the aircraft industry should, in due course, go to the Ministry of Technology, together with most of the research and development functions: responsibility for civil aviation would go to the Board of Trade. Responsibility for the shipbuilding industry would also be transferred from the Board of Trade to the Ministry of Technology, thus placing both the aircraft and the shipbuilding industry ministerially with the rest of the engineering industry. Mr. Wilson said the decision was also in line with the Government's declared policy to transfer more and more of its research from defence to civil industry. Responsibility for the supervision of the air corporations and independent airlines would remain with the present Minister of Aviation until decisions had been taken regarding future purchasing programmes of the airline corporations, but all other aspects of eivil aviation would be transferred immediately to the Board of Trade.

While it was intended to transfer most of the research and development work conducted by the Ministry of Aviation to the Ministry of Technology, a comprehensive examination was being made to determine to what extent procurement responsibilities of the Ministry of Aviation might more appropriately be transferred to the Ministry of Defence, and this examination could be completed before the Ministry of 'lechnology assumed their new responsibilities. Questioned further as to the future of the Royal Radar Establishment and the other Royal Establishments such as Farnborough, Mr. Wilson said that their importance was growing in the civil field and particularly in electronic developments for export. There was no question of fragmenting the Royal Radar Establishment and he expected that responsibility for it would pass, together with responsibility for the electronics indus. try, to the Ministry of Technology.

In a written answer in the House of Commons on June 16, the Minister of State for Education and Science. Mr. G. Roberts, stated that the Patont Office building was transferred from the Board of Trade to the British Museum on April 1, to form, with the Museum's own collection of scientific literature, the nucleus of the National Reference Library of Science and Invention. Temporary accommodation in London has been found for that part of the total collection which could not be housed in the existing Patent Office building, and the Ministry of Public Building and Works was negotiating a site for a permanent building. The library will offer its users an information retricval service, but it is too early to say what part the library will play in the mechanization of storage and retrieval of information.

IN answer to a question in the House of Lords on June 16, Lord Champion said that the Selective Employment Payments Bill contains a provision that will bring into entitlement for the selective employment premium those establishments certified by the Minister of Tech. nology to be engaged in scientific research relevant to manufacturing activities. This includes independent laboratories working for manufacturing industry. Establishments of this kind do not conform to any set pattern and every case will have to be judged on its merits. The clause is intended to ensure that such organizations receive equitable treatment.

\section{University News:}

London

Dr. A. B. Foster, reader in organic chemistry at the University of Birmingham, has been appointed to the chair of chemistry in the Institute of Cancer Research, Royal Cancer Hospital. Dr. N. Lichfield has been appointed to the chair of economics of town planning. tenable at University College. The title of professor has been conferred on the following: Dr. L. S. Bosanquet (mathematics, in respect of his post at University College); Dr. F. F. Heymann (physics, in respect of his post at University College); Dr. J. L. Mongar (pharmacology, in respect of his post at University College).

\section{Massachusetts Institute of Technology}

DR. J. P. Rurna, professor of electrical engineering at the Massachusetts Institute of Technology, who has been on leave since Septembor 1964 while serving as president of the Institute for Defense Analyses in Washington. D.C., will return to M.I.T. on July 1, as vico-president for special laboratories. He will be the Institute's senior officer on matters relating to the two national service laboratories the Institute administers for the Federal Government-Lincoln Laboratory and Instrumentation. Laboratory. Dr. Thomas K. Sherwood has been appointed as the first to occupy the Lammot du Pont professorship of chemical engineering. Prof. Sherwood is one of the world's leading authorities on fluid flow and mass transfer, and wrote the first significant text in this field, Absorption and Extraction, in 1937.

Pennsylvania

Dr. Charles C. Price has been appointed University professor of chemistry in the University of Pennsylvania. University professorships were established at Pennsylvania in 1961 to honour those faculty members who aro 